\title{
PENENTUAN PEMILIHAN BAHAN DALAM PEMBUATAN ACUAN ALAS KAKI SECARA MANUAL
}

\author{
Abimanyu Yogadita Restu Aji *)
}

\begin{abstract}
Reference of shoe last is something quite unique. In making the reference of footwear, special raw materials are required to produce a reference with good quality. The quality of this reference is very influential on the long life of a reference. In addition, the quality of the raw materials used also affects the shape of a reference. The research question posed is what factors determine the criteria for selecting the material, in the process of making the reference of footwear by manual technique. Data collection methods generally refer to interview techniques based on the principle, namely structured interviews, semi-structured and unstructured. Data analysis techniques use a gradual coding system with a focus of attention on the factors that determine the material selection criteria in manual reference footwear generation.
\end{abstract}

Keywords: Reference of footwear, manuals, material characters

ABSTRAK

Acuan alas kaki merupakan sesuatu yang cukup unik. Dalam pembuatan acuan alas kaki, diperlukan bahan baku khusus agar menghasilkan acuan dengan kulitas yang baik. Kualitas acuan ini sangat berpengaruh terhadap lama pakai dari sebuah acuan. Selain itu, kualitas dari bahan baku yang digunakan juga berpengaruh terhadap bentuk dari sebuah acuan. Pertanyaan penelitian yang diajukan adalah faktor apa yang menentukan kriteria pemilihan bahan, dalam proses pembuatan acuan alas kaki dengan teknik manual. Metode pengumpulan data secara umum mengacu pada teknik wawancara berdasarkan prinsipnya, yaitu wawancara terstruktur, semi terstruktur dan tidak terstruktur. Teknik analisis data menggunakan sistem pengkodean secara bertahap dengan fokus perhatian pada faktor yang menentukan kriteria pemilihan bahan dalam pembuatan acuan alas kaki secara manual.

Kata kunci : Acuan alas kaki, manual, karakter bahan

\section{PENDAHULUAN}

Di era teknologi yang sudah maju, banyak pekerjaan manusia dikerjakan dengan bantuan mesin. Banyak pula temuan-temuan manusia yang bergerak secara masinal untuk meringankan beban dari pekerjaan manusia. Hal tersebut juga banyak terjadi dalam dunia industri. Dalam dunia industri hal tersebut menjadi sebuah tuntutan untuk mengikuti perkembangan zaman dalam persaingan antar industri. Pembuatan produk yang dikerjakan secara masinal, dianggap memberikan hasil yang lebih baik daripada pembuatan produk yang dilakukan secara manual. Proses pembuatan produk secara masinal juga terjadi dalam pembuatan acuan alas kaki. Pembuatan acuan alas kaki dengan teknik

* Abimanyu Yogadita Restu Aji ( abimanyuyr@gmail.com), Mahasiswa Program Pascasarjana Institut Seni Indonesia Yogyakarta 
manual seperti menjadi pilihan kedua setelah masinal. Padahal dalam prakteknya jika terjadi kekeliruan pada pembuatan produk acuan alas kaki secara masinal, pengerjaan revisi dilakukan dengan cara manual.

Dalam buku Teknologi Sepatu Bagian I (1984) aturan umum dalam membuat sepatu adalah mengenai bentuk dan kesesuaian pakai, untuk mendapat bentuk sepatu dan kesesuaian pakai tersebut diperlukan suatu cetakan yang lazim disebut acuan atau last dalam bahasa Inggris. Dapat diartikan secara umum, acuan adalah sebuah cetakan sebagai pengganti dari kaki. Hal tersebut karena dalam pembuatan alas kaki, bentuk dan kesesuaian pakai merupakan poin yang penting. Sehingga alas kaki yang dihasilkan dapat terasa nyaman dipakai.

Acuan alas kaki merupakan sesuatu yang cukup unik. Dalam pembuatan acuan alas kaki, diperlukan bahan baku khusus agar menghasilkan acuan dengan kulitas yang baik. Kualitas acuan ini sangat berpengaruh terhadap lama pakai dari sebuah acuan. Selain itu, kualitas dari bahan baku yang digunakan juga berpengaruh terhadap bentuk dari sebuah acuan Terlebih dalam pembuatan acuan alas kaki dengan teknik manual, diperlukan bahan baku pilihan untuk dapat menunjang kualitas acuan yang dihasilkan.

Dalam jurnal The Hong Kong Polytechnic yang berjudul Design and manufacture of shoe lasts (2013), pembuatan acuan secara tradisional menggunakan kayu, dimana bahan tersebut merupakan bahan yang paling efektif dan ekonomis. Hingga hari ini, pembuatan acuan secara manual masih digunakan untuk pembuatan modifikasi alas kaki berkelas dan karya seni.

Dalam Last blocks and shoe last manufactured thereform (1962), telah menjadi kebiasaan untuk membuat acuan dengan cara mengurangi bahan mentah berupa balok kayu dengan ukuran yang diinginkan. Kayu maple adalah bahan yang paling sering digunakan, namun kayu maple memiliki kelemahan. Dikarenakan pasokan yang langka, mengakibatkan harganya mahal.

Dalam buku Boots and Shoes (2007) ,banyak varietas dari kayu untuk dipilih menjadi acuan, tetapi kayu yang cocok digunakan membuat acuan harus memenuhi karakteristik tertentu. Diantaranya harus keras dan tidak menyerap air.

Dari beberapa kajian yang telah dilakukan, dapat disebut bahwa pembuatan alas kaki dengan teknik manual merupakan teknik pembuatan acuan secara tradisional. Dalam pembuatannya, bahan yang digunakan berupa kayu dengan alasan bahan tersebut merupakan bahan yang efektif dan ekonomis. Pembuatan acuan alas kaki dengan teknik manual pada masa kini biasanya digunakan untuk kepentingan tertentu. Bukan untuk menopang industri alas kaki, melainkan untuk melayani pembuatan alas kaki secara custom atau modifikasi alas kaki dan untuk kepentingan seni. Pada zaman dahulu, bahan baku kayu yang digunakan dalam pembuatan acuan di Eropa adalah kayu maple, namun dikarenakan kelangkaan pasokan harus mencari alternatif bahan yang lain untuk menekan biaya produksi. Karakter yang dibutuhkan sebagai bahan baku dalam pembuatan acuan alas kaki secara manual 
harus merupaka kayu yang keras dan tidak menyerap air.

Dalam jurnal The Hong Kong Polytechnic yang berjudul Design and manufacture of shoe lasts (2013), acuan berbahan aluminium banyak digunakan pada proses produksi masal dengan menggunakan mesin, sebab acuan berbahan aluminium stabil saat proses produksi dan dapat di daur ulang. Acuan berbahan plastik solid paling banyak digunakan dalam pembuatan secara masal. Keuntungan acuan berbahan plastik solid diantaranya : stabil dan ramah lingkungan, memiliki presisi yang tinggi, waktu pakai yang lama, dapat di daur ulang, dapat diaplikasikan dengan mudah.

Dalam pembuatan acuan diperlukan bahan dan perlakuan khusus agar acuan tersebut dapat digunakan secara maksimal. Pembuatan acuan dengan teknik manual menggunakan bahan kayu sebagai bahan yang dianggap paling efektif dan ekonomis. Pembuatan acuan secara manual di eropa pada waktu itu lazim menggunakan bahan kayu maple. Namun dikarenakan sulitnya pasokan bahan baku, penggunaan kayu dirasa kurang efektif. Kemudian muncul acuan dengan bahan aluminium dan plastik solid. Hal tersebut dikarenakan sisa potongan bahan masih dapat digunakan kembali, sehingga tidak ada bahan yang terbuang. Pada saat ini acuan kayu sudah tidak digunakan di industri alas kaki, hal tersebut dikarenakan modernisasi yang terjadi pada industri alas kaki sudah tidak memungkinkan menggunakan acuan kayu. Hal tersebut berkaitan dengan keunggulan yang terdapat pada tipe acuan dengan bahan lain, diantaranya : bisa di daur ulang, waktu pakai lama, stabil dan ramah lingkungan. Penggunaan acuan secara manual lebih ditujukan untuk melayani pembuatan alas kaki secara custom atau modifikasi alas kaki dan untuk kepentingan seni. Acuan manual digunakan sebagai acuan produk alas kaki ekslusif bukan sebagai acuan untuk membuat produk masal.

Dalam prakteknya, pembuatan produk acuan dengan teknik manual umumnya menggunakan bahan baku berupa kayu. Sedangkan kayu yang tersedia, sangat beragam jenisnya dan memiliki karakter kayu berbeda-beda. Untuk dapat menghasilkan acuan alas kaki dengan kualitas yang bagus, tentunya diperlukan kriteria khusus berkaitan dengan bahan baku yang digunakan. Apakah segala jenis kayu dapat digunakan sebagai bahan dasar dalam pembuatan acuan alas kaki dengan teknik manual ? Lalu, alasan apa yang mendasari harus terdapat kriteria khusus dalam pemilihan bahan pembuatan acuan dengan teknik manual ? Dua hal tersebut menjadi faktor yang penting, dikarenakan kriteria apa saja yang diperlukan dalam pemilihan bahan baku dalam pembuatan acuan teknik manual, saling terkait dengan alasan mengapa kriteria itu diperlukan. Dengan memahami kriteria karakter bahan yang dibutuhkan tersebut, diharap dapat ditemukan pengetahuan baru mengenai penentuan kriteria pemilihan bahan dalam teknik pembuatan acuan alas kaki secara manual. Hal tersebut yang menjadi alasan utama peneliti untuk meneliti hal tersebut.

Bagaimana perajin menentukan kriteria kayu dan faktor apa yang berpengaruh terhadap penentuan pemilihan bahan baku pembuatan acuan 
dengan teknik manual, menjadi pokok permasalahan yang ingin diangkat. Kriteria seperti apa yang dibutuhkan dalam pemilihan bahan baku pembuatan acuan. Dengan memahami kriteria karakter bahan yang dibutuhkan tersebut, diharap dapat ditemukan pengetahuan baru mengenai penentuan kriteria pemilihan bahan dalam teknik pembuatan acuan alas kaki secara manual.

\section{METODE}

Peneliti mengambil topik tentang faktor apa yang menentukan kriteria pemilihan bahan, dalam proses pembuatan acuan alas kaki dengan teknik manual, didasari oleh ketertarikan peneliti mengenai hasil olahan produk secara manual. Peneliti merasa tertarik mengangkat topik ini karena dunia tersebut dianggap dekat dengan peneliti. Dalam pembuatan acuan dengan teknik manual, bahan baku utama adalah kayu. Namun menjadi pertanyaan utama dalam penelitian ini adalah, bagaimana menentukan kayu yang tepat untuk digunakan sebagai bahan baku pembuat acuan. Jika dilihat dari bahan baku berupa kayu, tentu terdapat berbagai pertimbangan untuk menentukan kayu yang tepat dijadikan sebagai bahan baku pembuat acuan. Karena setiap kayu memiliki karakter khusus tertentu. Berbagai pertimbangan berkaitan dengan karakter kayu yang dibutuhkan dalam pembuatan acuan dengan teknik manual, diduga memiliki alasan khusus. Sehingga yang menjadi fokus adalah, tentang faktor apa yang menentukan kriteria pemilihan bahan, dalam proses pembuatan acuan alas kaki dengan teknik manual.
Penelitian ini dilakukan bertempat di Yogyakarta tepatnya di Dusun Glugo, Sewon, Bantul. Alasan dipilihnya lokasi ini adalah tempat ini merupakan satu-satunya pengerajin acuan alas kaki dengan teknik manual yang ada di Yogyakarta, selain itu akses ke lokasi ini dirasa tidak terlalu jauh karena berdekatan dengan kampus sehingga masih memungkinkan untuk melakukan penelitian di tempat ini. Selain itu, peneliti sudah mengenal narasumber cukup lama. Sehingga akses untuk melakukan wawancara kepada narasumber dapat diperoleh secara maksimal. Dengan harapan dapat memperoleh data maupun informasi secara lengkap.

\section{HASIL DAN PEMBAHASAN}

Penelitian ini ingin menemukan mengenai bagaimana menentukan kriteria pemilihan bahan, dalam proses pembuatan acuan alas kaki dengan teknik manual. Untuk menjawab pertanyaan tersebut peneliti melakukan wawancara kepada narasumber terkait kriteria pemilihan bahan pembuatan acuan. Dalam penelitian ini dilakukan wawancara sebanyak tiga kali, untuk waktu wawancara tidak terjadwal dan hanya menyesuaikan dengan waktu dari narasumber. Penelitian ini dilakukan di Desa Glugo, Panggungharjo, Sewon, Bantul yang merupakan tempat pembuatan acuan alas kaki secara manual.

$$
\text { Dalam menentukan kriteria }
$$
pemilihan bahan, dalam proses pembuatan acuan alas kaki dengan teknik manual, secara garis besar terdapat dua poin penting. Yang pertama adalah bagaimana kriteria pemilihan bahan tersebut ditentukan dan alasan apa yang mendasari kriteria yang dibutuhkan tersebut sehingga 
dianggap penting sebagai kriteria utama. Selain itu terdapat kondisi dan syarat khusus yang diduga penting, yang mempengaruhi pemilihan bahan baku.

\section{Kebutuhan kriteria bahan}

Dalam menentukan kriteria pemilihan bahan, terdapat beberapa kriteria karakter kayu yang dibutuhkan agar dapat menghasilkan acuan yang berkualitas. Kebutuhan kriteria tersebut meliputi, kering, renyah, keras, halus, dan daya tahan bagus. Maksud dari kriteria kering adalah kayu yang menjadi bahan baku pembuatan acuan hendaknya berupa kayu yang telah benar-benar kering. Hal tersebut dikarenakan jika menggunakan kayu yang masih basah dimungkinkan terjadi penyusutan dan dapat merubah ukuran acuan. Renyah yang dimaksud pada kriteria ini adalah kayu yang memiliki karakter keras, namun juga memiliki serat kayu yang mudah diputus, sehingga menjadikannya kayu yang mudah dibentuk. Hal tersebut diduga sangat berpengaruh terhadap proses pembentukan dari sebuah acuan. Walaupun bahan baku yang digunakan memiliki karakter kayu yang keras, jika kayu tersebut memiliki serat yang mudah putus, diduga akan memudahkan dalam proses pembentukannya.

Kriteria keras dapat diartikan bahwa kayu yang digunakan sebagai bahan pembuat acuan hendaknya memiliki kepadatan dan tidak mudah berubah bentuk jika dipukul dengan menggunakan palu. Dalam melihat hal ini menggunakan sudut pandang pemakai acuan (perajin alas kaki), hal tersebut berkaitan pada proses lasting saat acuan digunakan untuk merakit alas kaki. Dalam proses lasting pada saat perakitan alas kaki, upper alas kaki dipasang dengan cara membalutkannya ke acuan sesuai dengan pola dan model yang telah ditentukan. Pada saat lasting tersebut, pemasangan upper biasanya dilakukan dengan cara dilem dengan bottom alas kaki. Saat merekatkannya, biasanya dilakukan dengan cara memukul upper ke acuan agar sesuai dengan alas kaki yang diinginkan. Kriteria halus juga dilihat dari sudut pandang pemakai. Dengan memiliki karakter bahan yang halus, maka hasil jadi dari acuan tidak akan berserabut, hal tersebut sangat membantu pada saat perakitan alas kaki, khususnya pada saat proses lasting sepatu. Pada proses lasting dibutuhkan acuan yang halus, dikarenakan saat melepaskan acuan dari alas kaki yang telah selesai lasting, jika acuan tidak memiliki permukaan yang halus diduga akan terjadi kesulitan atau menghambat pada saat melepaskan acuan dari alas kaki yang telah selesai. Kriteria daya tahan dimaksudkan bahwa bahan pembuat acuan harus memiliki daya tahan yang baik, ditandai dengan kayu yang tidak dimakan rayap dan proses penyusutannya cepat. Dengan proses penyusustan yang cepat, maka nomer acuan akan semakin akurat. Yang dimaksudkan kayu yang memiliki proses penyusutan yang cepat adalah kondisi dimana kayu masih dalam keadaan basah sehabis ditebang dan sewaktu proses pengeringan. Karena setelah kayu kering dengan maksimal, tidak terjadi lagi proses penyusutan.

\section{Kondisi khusus}

Kondisi khusus yang dimaksud berkaitan dengan syarat karakter kayu pada satu pasang acuan. Dalam satu pasang 
acuan, harus memiliki arah serat kayu yang sama. Hal tersebut erat kaitannya dengan penyusustan. Jika arah serat dalam satu pasang acuan berbeda, maka dimungkinkan terjadi perbedaan arah penyusutan setelah acuan tersebut jadi. Perbedaan arah serat tersebut memiliki efek yang besar terhadap acuan jadi. Jika terdapat sepasang acuan alas kaki dengan perbedaan arah serat didalamnya, dimungkinkan hasil jadi acuan tersebut berbeda. Sebagai ilustrasi, jika salah satu dari acuan tersebut berbeda arah seratnya, pada saat proses penyusutan dimungkinkan salah satu dari acuan tersebut menjadi lebih pendek dari acuan pasangannya. Hal itu disebabkan oleh arah serat kayu yang berbeda pada sepasang acuan alas kaki.

Selain itu terdapat penempatan posisi hati kayu, hati kayu merupakan bagian tengah kayu yang rawan rusak. Sehingga penempatannya dalam pembuatan acuan harus diperhatikan dan tidak boleh terletak di bagian tepi acuan. Penempatan hati kayu diduga mempertimbangkan perlakuan khusus yang diterima dari acuan alas kaki pada saat proses lasting. Dengan tidak menempatkan bagian hati kayu di bagian tepi dari acuan alas kaki, akan meminimalisir kerusakan yang mungkin diterima acuan alas kaki yang ditimbulkan dari bagian hati kayu. Karena jika penempatan hati kayu diletakkan pada bagian tepi dari acuan, dikhawatirkan acuan alas kaki akan rusak atau pecah jika acuan alas kaki menerima pukulan-pukulan pada saat proses lasting.

\section{Poin utama}

Poin penting dalam menentukan kriteria pemilihan bahan, dalam proses pembuatan acuan alas kaki dengan teknik manual, terletak pada kebutuhan kriteria bahan dan kondisi khusus. Dalam kebutuhan kriteria bahan, diperlukan kayu yang memiliki kriteria kering, keras, renyah, halus dan daya tahan yang bagus. Hal tersebut berhubungan pada saat proses pengerjaan acuan alas kaki dan dilihat dari sudut pandang pengguna, saat acuan alas kaki tersebut digunakan.

Dalam kondisi khusus, hal ini sangat berkitan dengan arah serat dari kayu tiap pasang acuan. dengan perbedaan serat, dimungkinkan terjadi perbedaan penyusutan sehingga terjadi perbedaan bentuk dalam satu pasang acuan yang telah jadi. Selain itu penempatan posisi hati kayu tidak boleh ditaruh dibagian tepi acuan, karena akan mengakibatkan kerusakan.

\section{PENUTUP}

Berdasarkan pembahasan hasil penelitian, maka dapat ditarik kesimpulan bahwa menentukan pemilihan bahan, dalam proses pembuatan acuan alas kaki dengan teknik manual memiliki kriteria khusus. Dalam kriteria tersebut saling berkaitan dalam kondisi khusus sebuah kayu untuk membentuk kayu menjadi sebuah acuan. Sehingga dapat disimpulkan bahwa :

Kebutuhan kriteria khusus yang diperlukan dalam pembuatan acuan berupa kayu yang kering, renyah, keras, halus dan memiliki daya tahan yang bagus. Dalam hal ini hal tersebut dipandang melalui sudut pandang pembuat dan sudut pandang pemakai acuan. Kedua sudut pandang tadi berkaitan erat dengan bagaimana proses acuan alas kaki tersebut dibuat dan dikerjakan serta bagaimana acuan alas kaki 
tersebut digunakan setelah proses pembuatannya selesai. Hal tersebut dilakukan agar menghasilkan acuan yang berkualitas namun mudah dalam pengerjaannya serta memudahkan dalam penggunaannya setelah jadi.

Kondisi khusus merupakan kondisi yang berkaitan antara kriteria khusus dengan syarat tertentu dalam pembuatan acuan. Kondisi khusus tersebut berupa arah serat kayu tiap pasang acuan, dalam tiap pasang acuan hendaknya memiliki arah serat kayu yang searah agar memiliki kesamaan bentuk jika masih terjadi penyusutan. Jika terdapat sepasang acuan alas kaki dengan perbedaan arah serat didalamnya, dimungkinkan hasil jadi acuan tersebut berbeda. Sebagai ilustrasi, jika salah satu dari acuan tersebut berbeda arah seratnya, pada saat proses penyusutan dimungkinkan salah satu dari acuan tersebut menjadi lebih pendek dari acuan pasangannya. Lalu terdapat hati kayu yang tidak boleh diletakkan dibagian tepi acuan karena hati kayu merupakan bagian kayu yang mudah rapuh/rusak. Pertimbangan penempatan hati kayu didasari dengan sudut pandang pengguna, karena saat acuan alas kaki digunakan terdapat perlakuan berupa pukulan-pukulan untuk lasting alas kaki pada acuan.

\section{DAFTAR PUSTAKA}

A. Luximon. 2013. Handbook of Footwear Design and Manufacture. Hongkong Polytechnic University.

Basuki, Dwi Asdono. 1984. Teknologi Sepatu Bagian 1. Akademi Teknologi Kulit Yogyakarta
Dooley, William. 1912. A Manual Of Shoemaking And Leather And Rubber Products. Little, Brown, and company, Boston

Glanville, Worswick. 2007. Boots and Shoes volume 1. New Era Publishing. London

M. Bialy, Freidich .1962. Last blocks and shoe last manufactured thereform. Leslyn Products Corp . 